\title{
EFFECTS OF DIFFERENT FORMS OF NITROGEN FERTILIZERS ON ARSENIC UPTAKE BY RICE PLANTS
}

\author{
Xue-Ping Chen, $\dagger$ Yong-Guan Zhu, $* \dagger+$ Mi-Na Hong, $§$ Andreas Kappler, $\|$ and Yu-Xin Xu§ \\ $\dagger$ Research Center for Eco-Environmental Sciences, Chinese Academy of Sciences, Beijing 100085, China \\ $\$$ Institute of Urban Environment, Chinese Academy of Sciences, Xiamen 361003, China \\ $\S$ College of Environment and Resource, Shandong Agricultural University, Tai'an 271018, China \\ ||Geomicrobiology Group, Center for Applied Geosciences, University of Tübingen, Tübingen 72076, Germany
}

(Received 15 June 2007; Accepted 11 October 2007)

\begin{abstract}
A pot microcosm experiment was conducted to investigate the effect of different forms of $\mathrm{N}$ fertilizers on As uptake by rice. Compared to a nontreated control, addition of nitrate reduced $\mathrm{Fe}(\mathrm{II})$ concentration in soil solution, while treatment with ammonium enhanced $\mathrm{Fe}$ (III) reduction, probably coupled to $\mathrm{NH}_{4}^{+}$oxidation in the nonrhizosphere. Most-probable-number (MPN) enumerations revealed high densities of nitrate-dependent Fe(II)-oxidizing microorganisms. The addition of nitrate decreased Fe plaque formation on the root surface, accompanied by much lower dissolved Fe(II) concentrations in the rhizosphere soil solution compared to the nonamended control. Nitrate addition also reduced As uptake by the rice plant. These results suggest that nitrate may inhibit $\mathrm{Fe}$ (III) reduction and/or stimulate nitrate-dependent $\mathrm{Fe}(\mathrm{II})$ oxidation, leading to As coprecipitation with, or adsorption to, Fe(III) minerals in the soil. Although Fe plaque formation on the root surface is reduced, nitrate-dependent stimulation of Fe(II) oxidation and/or inhibition of $\mathrm{Fe}(\mathrm{III})$ reduction in the bulk soil sequesters mobile As in the soil, resulting in reduced As uptake by rice.
\end{abstract}

Keywords-Nitrate-dependent iron oxidation Iron plaque Most probable number Arsenic Paddy soil

\section{INTRODUCTION}

Arsenic is a toxic metalloid widely distributed in the earth's crust, most notably in the groundwater of southeast Asia, where water from tube wells is often used for irrigating rice fields. Intensive use of water from these As-contaminated aquifers has led to an As buildup in paddy soils and resulted in 10-fold elevated As levels in rice grains [1]. Therefore, the transfer of As in soil-rice systems can amplify the risk of As to people living in those regions [2].

Arsenic accumulation in rice is controlled by an array of factors, including bioavailability, rhizosphere processes, and metabolism in rice plants. Arsenic chemistry in paddy soils is extremely complex, because soils are subject to frequent redox cycles in both time and space. Iron cycling is believed to be an important factor in regulating As bioavailability [3-5]. Under flooding conditions, As is released following Fe(III) reduction when $\mathrm{O}_{2}$ in paddy soils is consumed rapidly by aerobic bacteria and by chemical oxidation processes. Nitrate is the first alternative electron acceptor in the anoxic region [6,7], and $\mathrm{Fe}$ (III) reduction can be inhibited by denitrification through biotic and abiotic processes [7]. Therefore, the addition of nitrate to a paddy may inhibit the release of As into soil solution.

The oxidation of $\mathrm{Fe}(\mathrm{II})$ back into $\mathrm{Fe}(\mathrm{III})$ will influence the bioavailability of As through coprecipitation and/or adsorption to $\mathrm{Fe}(\mathrm{III})$ minerals. Compared with abiotic $\mathrm{Fe}(\mathrm{II})$ oxidation by oxygen, chemical oxidation of $\mathrm{Fe}(\mathrm{II})$ by nitrate is slow in the absence of a catalyst (dissolved $\mathrm{Cu}$ ) [8]. The potential for biotic $\mathrm{Fe}(\mathrm{II})$ oxidation under anoxic conditions has been suggested by the discovery of nitrate-dependent, Fe-oxidizing bacteria

* To whom correspondence may be addressed (ygzhu@mail.rcees.ac.cn).

Published on the Web 11/20/2007.
[9-11]. Nitrate-dependent Fe(II) oxidizers are widespread in different habitats, such as freshwater sediments [12-14], sewage sludge systems $[15,16]$, and paddy soils $[17,18]$. In addition, some known denitrifying bacteria were found to oxidize $\mathrm{Fe}(\mathrm{II})$ simultaneously $[13,14,19]$. The ubiquity of nitrate-dependent $\mathrm{Fe}$ (II) oxidation in the environment suggests that the bacteria may play an important role in the redox cycle of $\mathrm{Fe}$ and $\mathrm{N}$ in these habitats. Microbially catalyzed, anaerobic Fe(II) oxidation represents a biological mechanism promoting the reoxidation of $\mathrm{Fe}(\mathrm{II})$ in anoxic environments [10], potentially contributing to a dynamic, microbially mediated, anoxic $\mathrm{Fe}$ redox cycle [11]. Nitrate-dependent $\mathrm{Fe}(\mathrm{II})$ oxidation can significantly influence soil and sediment mineralogy and geochemistry. The precipitation of biogenic Fe(III) oxides provides a mechanism for the immobilization of heavy metals and metalloids through coprecipitation or physical envelopment and provides a reactive surface with an adsorptive affinity for anions (e.g., $\mathrm{PO}_{4}^{3-}$ ) and cations (e.g., $\mathrm{Zn}^{2+}$ ) [20,21]. Senn and Hemond [22] demonstrated that nitrate strongly influences As cycling under anoxic conditions in an urban lake by oxidizing $\mathrm{Fe}(\mathrm{II})$ to produce As-sorbing, particulate, hydrous ferric oxides. Although the potential for biotic, nitrate-dependent Fe(II) oxidation in paddy soil has been demonstrated [8], the consequences of $\mathrm{Fe}$ oxidation for the fate of As are not understood at all.

Furthermore, in the rhizosphere, Fe(II) can be oxidized, resulting in the rust-colored precipitate of Fe oxides on the root surface (Fe plaque). Iron plaque has been shown to consist mainly of poorly crystalline Fe(III) minerals and to affect the distribution of P, As, and some heavy metals [23-28]. Liu et al. [29] suggested that As can be sequestered in Fe plaque on root surfaces of rice plants. Those authors also found that the extent of Fe plaque formation was governed by $\mathrm{P}$ status and 
that plaque formation decreased the uptake of As into rice. It has been suggested that $\mathrm{Fe}$ (II) oxidization in the rhizosphere and the subsequent formation of Fe plaque on the root surface mainly result from the chemical oxidation of $\mathrm{Fe}(\mathrm{II})$. Although it also has been reported that the interstitial space between the plaque and the root surface often are colonized by microorganisms [30,31], the role of the microbial oxidation of $\mathrm{Fe}(\mathrm{II})$ in the formation of Fe plaque and the biogeochemistry of As in the rhizosphere is still unclear.

The previously mentioned studies all indicate that a tight coupling between $\mathrm{N}, \mathrm{Fe}$, and As may exist in the paddy soilrice system and that addition of $\mathrm{N}$ may affect the fate of As in the system. The present study was undertaken to assess the impact of $\mathrm{N}$ addition on Fe and As chemistry in soil solution, Fe plaque formation, and As accumulation by rice. We hypothesize that nitrate-dependent, $\mathrm{Fe}(\mathrm{II})$-oxidizing bacteria are abundant in the paddy soil and that addition of $\mathrm{NO}_{3}^{-}$stimulates $\mathrm{Fe}(\mathrm{II})$ oxidation coupled to the reduction of $\mathrm{NO}_{3}^{-}$and, thus, indirectly affects Fe plaque formation and As geochemistry. The objectives of the present study therefore were to investigate the release of dissolved $\mathrm{Fe}$ (II) on $\mathrm{N}$ addition, to quantify the distribution and speciation of As in paddy soil solutions, to determine whether As accumulated in the Fe plaque is impacted by the addition of different forms of $\mathrm{N}$, and to elucidate if As accumulation in rice plants is altered by the addition of different forms of $\mathrm{N}$.

\section{MATERIALS AND METHODS}

\section{Pot experiment}

The paddy soil was obtained from a field contaminated with As $(84.92 \mathrm{mg} / \mathrm{kg}$ soil) in close vicinity to a $\mathrm{Pb} / \mathrm{Zn}$ mine at Shangyu (Zhejiang, China). The As concentration here is significantly higher than As concentrations typically found in paddy soils of southeast Asian countries (India and Bangladesh), where As concentrations in soil can be as much as 80 $\mathrm{mg} / \mathrm{kg}$ after irrigation with contaminated water [32]. Before the experiment, the soil was air-dried and sieved through a 2-mm mesh. Plants were allowed to grow with three different fertilizer treatments: Untreated soil (control), addition of $\mathrm{KNO}_{3}$, and addition of $\mathrm{NH}_{4} \mathrm{Cl}$ and $\mathrm{KCl}$ to compensate for addition of $\mathrm{K}$. Nitrogen (either $1 \mathrm{mM} / \mathrm{kg}$ soil nitrate or ammonium) was added every week. To evaluate the influence of the rice plant on rice paddy soil geochemistry, control experiments with sterilized ( $8 \mathrm{kGy}$ of ${ }^{60} \mathrm{Co}$ gamma-ray irradiation) or nonsterilized soils without rice were amended with fertilizers as described before.

Rice seeds (Oryza sativa L) cv. Jiahua-1 were disinfected in a $30 \% \mathrm{H}_{2} \mathrm{O}_{2}(\mathrm{w} / \mathrm{w})$ solution for $10 \mathrm{~min}$, followed by thorough washing with deionized water. The seeds were germinated in moist perlite. After three weeks, uniform seedlings were selected and transplanted into bags (nylon mesh size, $37 \mu \mathrm{m}$; diameter, $7.5 \mathrm{~cm}$; height, $10 \mathrm{~cm} ; n=1$ plant $/ \mathrm{bag}$ ) filled with $0.2 \mathrm{~kg}$ of sieved soil. The bags were placed in the center of $1.5 \mathrm{~kg}$ pots, and the gap between the nylon bag and the polyvinyl chloride (PVC) pot was filled with $0.8 \mathrm{~kg}$ of soil. This allowed separation of a root/rhizosphere compartment from a soil compartment. A rhizo-sampler (PVC tube; Rhizon Soil Moisture Samplers; Rhizosphere Research Products, Wageningen, The Netherlands) with a filter (mesh size, $0.45 \mu \mathrm{m}$ ) at one side and a syringe connected at the other side is a nondestructive, simultaneous, sequential, convenient, and rapid sampling tool for soil pore-water extraction and provides an in situ monitoring technique [33]. Two rhizo-samplers were

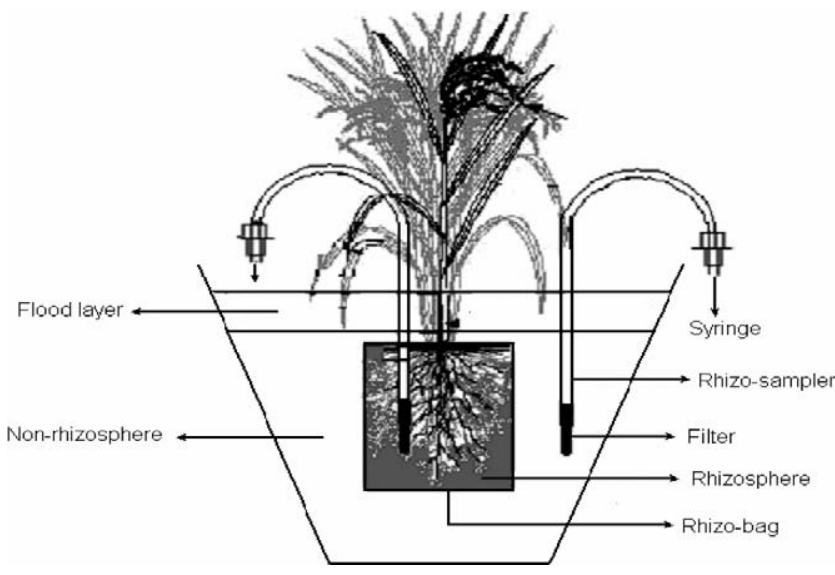

Fig. 1. Scheme of the experimental setup. Distinct compartments of rhizosphere (inside the root bag) and nonrhizosphere (outside of the root bag) separated by the root bag and rhizo-samplers (polyvinyl chloride tubes) with filters (mesh size, $0.45 \mu \mathrm{m}$ ) were embedded in soil at the same depth for extracting the soil solutions.

embedded in and out of the bag, respectively, at the same depth for each pot. To inhibit $\mathrm{N}_{2}$ fixation by cyanobacteria, the top of the pot was covered by black nylon with a gap to allow the rice to grow.

After being transplanted into the PVC pot, the rice plants were grown for five weeks in a greenhouse with a 10:14-h light:dark photoperiod. The temperature was kept at $25^{\circ} \mathrm{C}$ during the day and $16^{\circ} \mathrm{C}$ during the night, with a relative humidity of $70 \%$.

\section{Analysis of Fe/As species in soil solutions}

For the determination of nitrate, total As (As(tot)), Fe(II), and $\mathrm{Fe}(\mathrm{III})$, the soil solution samples were extracted by syringes through the PVC tubes every $2 \mathrm{~d}$ (Fig. 1). Inorganic As species were analyzed once a week. Nitrate was determined by ion chromatography (As14 column, Dionnex 600; Dionex, Sunnyvale, CA, USA). On extraction with syringes through the PVC tubes, soil solution was acidified by $\mathrm{HCl}(1 \mathrm{mM})$ to inhibit $\mathrm{Fe}(\mathrm{II})$ oxidation during storage (usually $2-4 \mathrm{~h}$ before analysis). The total $\mathrm{Fe}$ and $\mathrm{Fe}$ (II) concentrations were analyzed according to the method described by Ratering and Schnell [18]. Total As was quantified by an atomic fluorescent photometer (AF-610A; Beijing Ruili Analysis Instrument, Beijing, China). Arsenic species in the acidified soil solution were separated using As speciation cartridges obtained from X.G. Meng (Stevens Institute of Technology, Hoboken, NJ, USA) [34] that removed arsenate and did not adsorb arsenite. The difference between the As(tot) concentrations in the raw soil solution and the As(III) concentration in the filtered soil solution through the cartridges was identified as the concentration of $\mathrm{As}(\mathrm{V})$ in the soil solution.

\section{Extraction and determination of $\mathrm{Fe}$ plaque from roots}

At harvest, roots were washed gently with tap water to remove any soil particles adhering to the root surface and then excised at the basal node. The fresh root materials were incubated for $30 \mathrm{~min}$ at room temperature $\left(20-25^{\circ} \mathrm{C}\right)$ in $30 \mathrm{ml}$ of dithionite citrate bicarbonate (DCB) solution containing $0.03 \mathrm{M}$ sodium citrate $\left(\mathrm{Na}_{3} \mathrm{C}_{6} \mathrm{H}_{5} \mathrm{O}_{7} \cdot 2 \mathrm{H}_{2} \mathrm{O}\right)$ and $0.125 \mathrm{M}$ sodium bicarbonate $\left(\mathrm{NaHCO}_{3}\right)$, with the addition of $0.5 \mathrm{~g}$ of sodium dithionite $\left(\mathrm{Na}_{2} \mathrm{~S}_{2} \mathrm{O}_{4}\right)$ [35,36]. Roots were rinsed three times 
with deionized water, and the washing solutions were added to the DCB extracts. The resulting solution was filled up to $50 \mathrm{ml}$ with deionized water [29]. After DCB extraction, roots and shoots were oven-dried at $70^{\circ} \mathrm{C}$ for $3 \mathrm{~d}$ and then weighed. The concentrations of total $\mathrm{Fe}$ and $\mathrm{P}$ in the DCB extracts were measured by an inductively coupled plasma-optical emission spectrometer (Optima 2000 DV; PerkinElmer, Waltham, MA, USA), and As was analyzed by an atomic fluorescent photometer.

\section{Abundance of nitrate-dependent, Fe-oxidizing bacteria}

Nitrate-dependent, Fe-oxidizing microorganisms were enumerated using the most-probable-number (MPN) method as described by Ratering and Schnell [18]. To detach the bacteria from the soil particles, the nonrhizosphere and rhizosphere soil was diluted (1:100) and incubated in $2 \mathrm{mM}$ sodium pyrophosphate with glass beads and then shaken for $1 \mathrm{~h}$. Triplicate glass tubes containing defined sterile, anaerobic, bicarbonatebuffered (30 mM, pH 7.0) mineral medium [37], amended with $2 \mathrm{mM}$ acetate, $4 \mathrm{mM}$ nitrate, and $2 \mathrm{mM}$ ferrous sulfate from sterile anaerobic stock solutions, were inoculated with a serially diluted soil-water mixture ranging from $10^{-3}$ to $10^{-8}$. The tubes were incubated statically in the dark at $30^{\circ} \mathrm{C}$ for 10 weeks. The formation of orange precipitates indicated the oxidation of $\mathrm{Fe}(\mathrm{II})$ and the presence of nitrate-dependent, $\mathrm{Fe}(\mathrm{II})$ oxidizing microorganisms. A subset of positive tubes was examined microscopically to confirm cell growth. The MPN estimates were obtained using the Most Probable Number Calculator $\mathbb{C}$ (Ver 4.05; U.S. Environmental Protection Agency, Cincinnati, OH) (http://www.epa.gov/nerlcwww/other.htm).

\section{Data analysis}

All data were subjected to analysis of variance using SPSS ${ }^{\circledR}$ software (Ver 11.0; SPSS, Chicago, IL, USA).

\section{RESULTS}

\section{Plant biomass}

Shoot and root dry weights of rice with different $\mathrm{N}$ treatments were $0.51 \pm 0.04$ and $0.13 \pm 0.01 \mathrm{~g}$, respectively, with four replicates of each treatment. No significant differences were found between treatments (data not shown).

\section{Effect of $\mathrm{NO}_{3}^{-}$on $\mathrm{Fe}$ and As concentrations in soil solution}

In the nonrhizosphere soil, for each treatment (nonamended, nitrate-amended, and ammonium-amended soil) the concentrations and the changing trend of $\mathrm{Fe}(\mathrm{II})$ over time are shown in Figure 2A. No dissolved Fe(III) was detectable in all treatments (data not shown). Whereas Fe(II) concentrations in the treatment with nitrate were in the same concentration range as that in the control, the ammonium-amended soils showed significantly higher values for Fe(II). The changes in Fe(II) concentration in the nonrhizosphere soil solution over time can be divided into three phases: An increasing phase $(<10$ d), an invariable phase (11-21 d), and a phase with decreasing $\mathrm{Fe}(\mathrm{II})$ and total Fe concentrations (22-34 d).

Dissolved Fe(II) concentrations over time in the rhizosphere soil solution are shown in Figure 2B. In contrast to the nonrhizosphere soil solution, in the rhizosphere the $\mathrm{Fe}(\mathrm{II})$ concentrations in soil solution in the treatment with ammonia were similar to those in the control, and significantly lower values were observed in the treatment with nitrate. There also seemed to be an increasing phase $(<10 \mathrm{~d})$, an invariable phase $(11-$
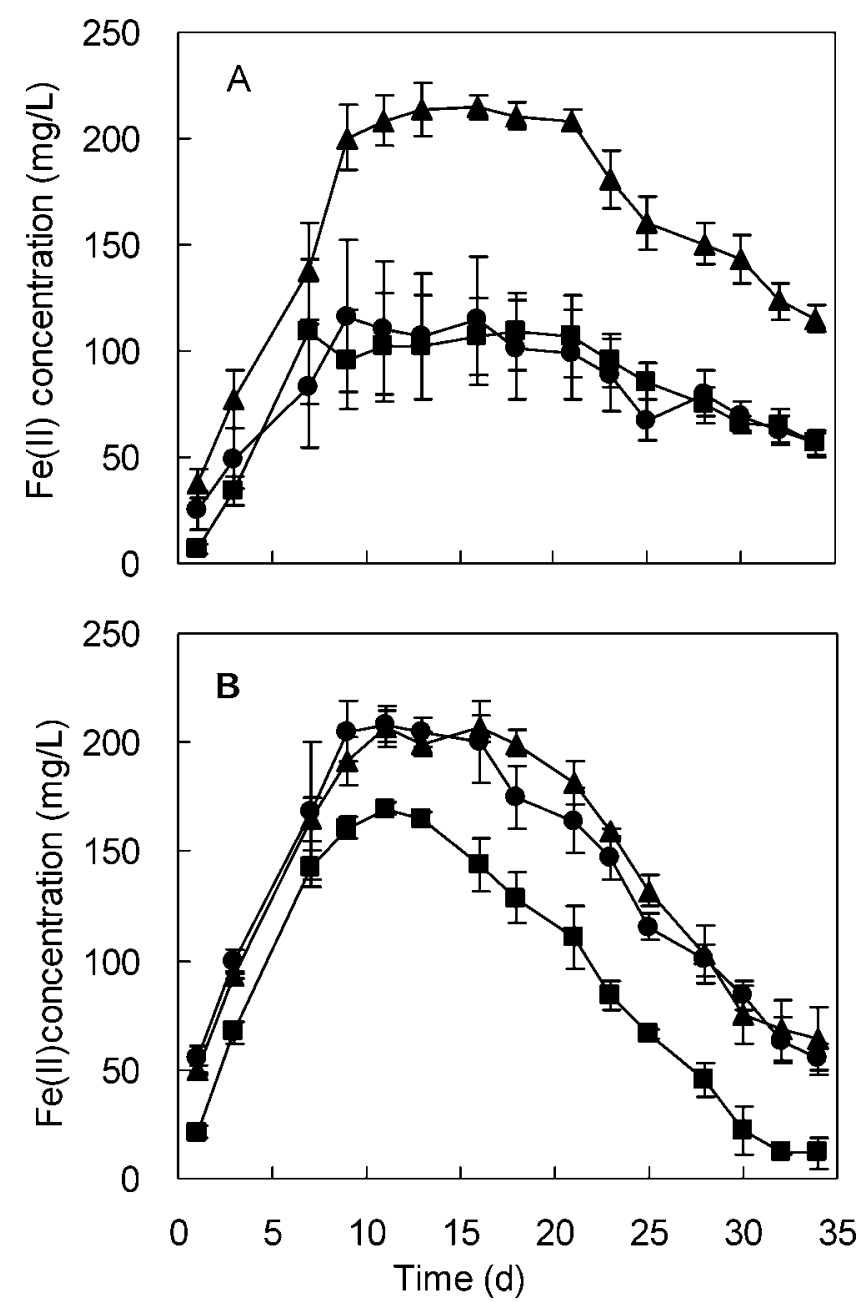

Fig. 2. Dissolved Fe(II) concentrations in extracted nonrhizosphere (A) and rhizosphere (B) soil solution. Error bars represent standard errors (mean of four replicates). $-\mathbf{-}=$ control; $-\square-=\mathrm{KNO}_{3}$; $\left.-\boldsymbol{\Lambda}-=\mathrm{NH}_{4} \mathrm{CI}\right)$.

$16 \mathrm{~d})$, and a phase with decreasing dissolved Fe(II) concentrations $(>16 \mathrm{~d})$.

The dissolved As(tot) concentrations in nonrhizosphere soil solution increased in the initial phase regardless of $\mathrm{N}$ amendments (Fig. 3). Dissolved As(tot) concentrations in soil solution with ammonia amendment was slightly higher than those in other treatments in the initial phase $(<16 \mathrm{~d})$ and decreased constantly thereafter. Dissolved As(tot) concentrations in nonrhizosphere soil solutions in the treatment with nitrate fluctuated over the experimental period. Dissolved As(III) concentrations in nonrhizosphere soil solution of the control were nearly constant during the experimental period (Fig. 3C). In the treatment with nitrate, dissolved As(III) concentration in nonrhizosphere soil solution increased first $(<17 \mathrm{~d})$, then decreased fast in the treatment with nitrate, which followed the same pattern as that of dissolved As(tot).

In rhizosphere soil solutions, the dissolved As(tot) concentrations also increased in the first phase $(<11 \mathrm{~d})$, then decreased constantly in the treatment with nitrate (Fig. 3). Dissolved As(tot) concentrations in rhizosphere soil solution in the treatment with nitrate amendment decreased faster and were much lower than those in the control and ammonia treatment during the last week (28-34 d). Furthermore, dissolved As(III) concentrations in rhizosphere soil solution with nitrate 

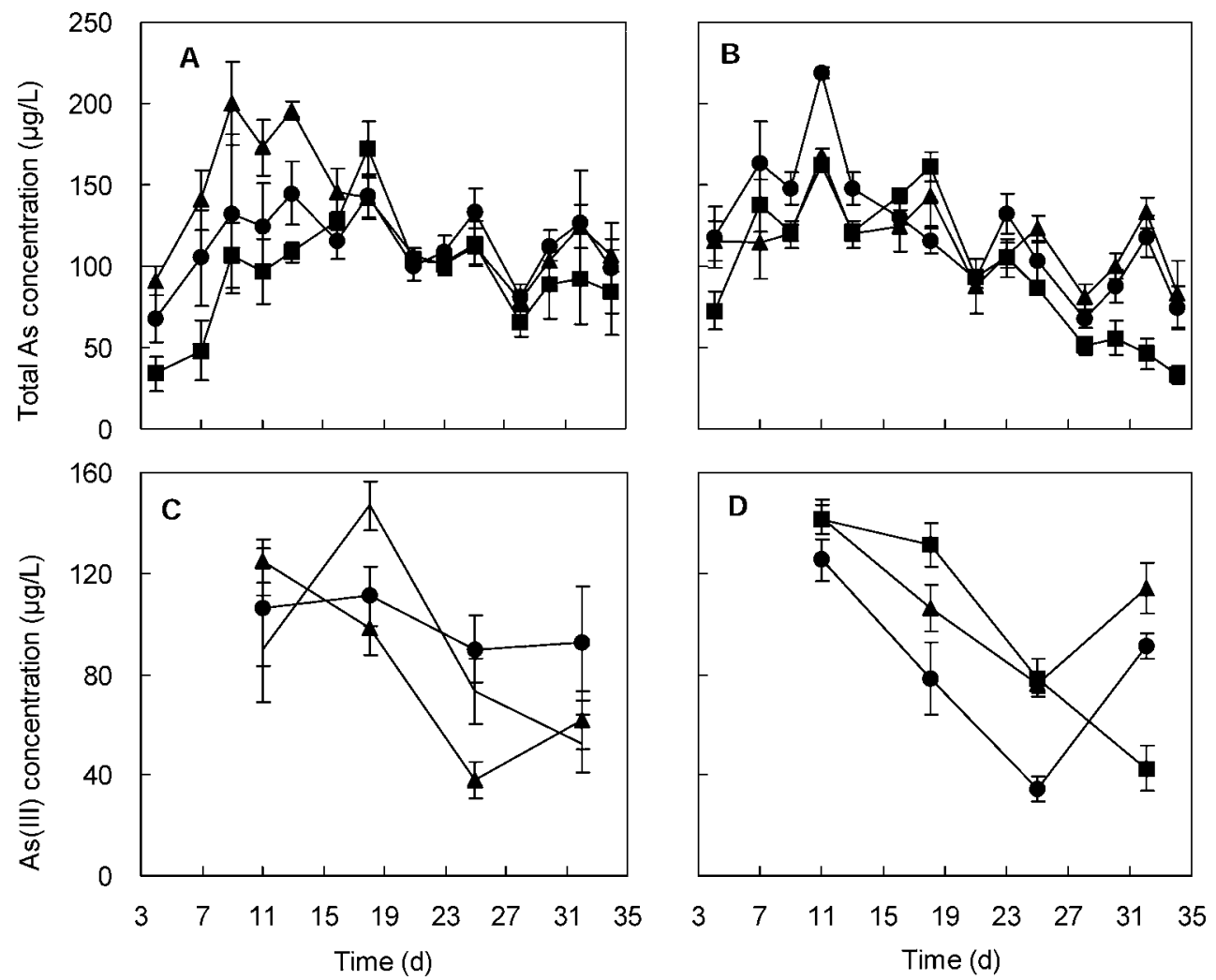

Fig. 3. Total As and As(III) concentrations in extracted nonrhizosphere (A and $\mathbf{C})$ and rhizosphere (B and $\mathbf{D})$ soil solution. Error bars represent standard errors (mean of four replicates). $--=$ control; $-\square-=\mathrm{KNO}_{3} ;-\boldsymbol{-}-=\mathrm{NH}_{4} \mathrm{CI}$.

amendment was constant before $17 \mathrm{~d}$ and then decreased quickly.

\section{Effect of $\mathrm{NO}_{3}^{-}$on Fe plaque formation}

Irrespective of $\mathrm{N}$ treatments, rice roots at harvest showed reddish-brown coatings, a color suggesting the presence of $\mathrm{Fe}$ oxides. The amount of $\mathrm{Fe}$ plaque was significantly lower $(\sim 50 \%)$ on roots in the treatment with nitrate addition as compared to the amount on roots in the control and ammonia treatment that showed comparable amounts of Fe precipitated on the root surface (Fig. 4).

The amount of $\mathrm{P}$ and As adsorbed to the plaque increased significantly with the amounts of plaque (Fig. 4). Phosphorus and As concentrations in the DCB extracts of the roots followed the pattern of $\mathrm{Fe}$ plaque, with less $\mathrm{P}$ and As in the nitrate treatment than in the control and ammonia treatment. Positive correlations were found between the $\mathrm{P}$ and As absorbed on the Fe plaque and the amount of Fe plaque (data not shown).

\section{$P$ and As uptake by rice}

Arsenic concentrations in rice roots and shoots showed a clear correlation with the amount of Fe plaque, with higher As concentrations in the root/shoot when the Fe plaque was more abundant (Table 1). Arsenic uptake by rice in the treatment with nitrate was significantly lower than that in the control ( $\sim 40 \%$ in both root and shoot). Irrespective of $\mathrm{N}$ treatments, $\mathrm{P}$ accumulation in the root did not show significant differences between treatments, whereas $\mathrm{P}$ concentration in shoots was significantly higher for the control than for $\mathrm{N}$ treatments (Table 1).

\section{MPN enumeration}

Cell numbers of nitrate-dependent, Fe(II)-oxidizing microorganisms in nonrhizosphere and rhizosphere soils after nitrate or ammonium amendments compared to nonamended soil are shown in Table 2. The MPN enumerations revealed the presence of significant populations of $\mathrm{Fe}(\mathrm{II})$-oxidizing, nitrate-reducing bacteria $\left(\sim 10^{4}-10^{6}\right.$ cells/g dry wt) in the paddy soil. Generally, the abundance of culturable, nitrate-dependent

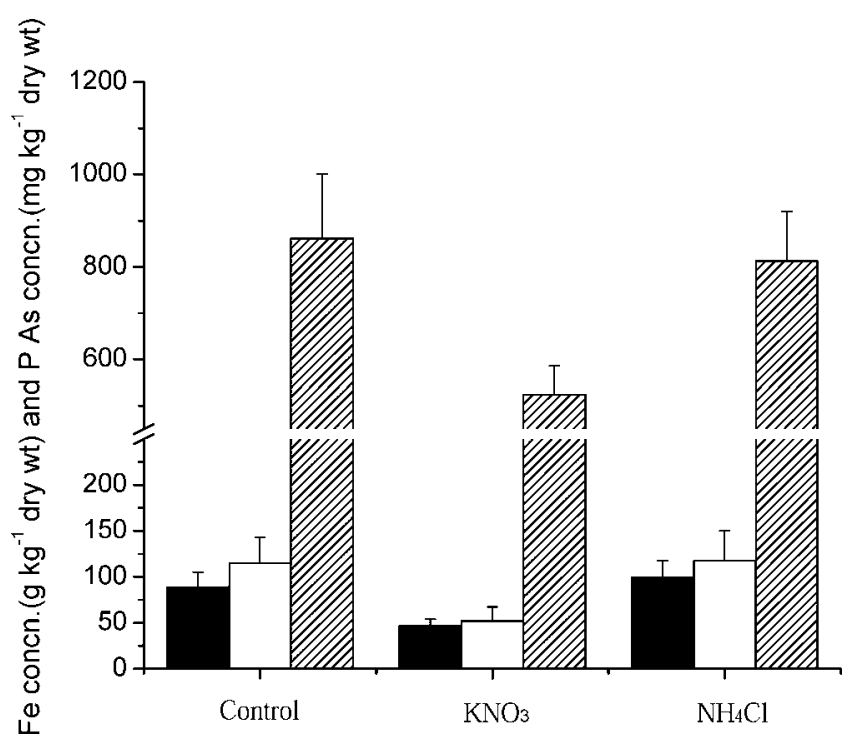

Fig. 4. Fe, $\mathrm{P}$, and As concentrations in the dithionite citrate bicarbonate solution from the rice roots. Error bars represent standard errors (mean of four replicates). $\square=\mathrm{Fe} ; \square=\mathrm{As}$; $\square=\mathrm{P}$. 
Table 1. Fe, As, and P distribution in root and shoot harvested after $34 \mathrm{~d}^{\mathrm{a}}$

\begin{tabular}{|c|c|c|c|c|c|c|}
\hline \multirow[b]{2}{*}{ Treatment } & \multicolumn{3}{|c|}{ Shoot concentration $(\mathrm{mg} / \mathrm{kg}$ dry wt) } & \multicolumn{3}{|c|}{ Root concentration (mg/kg dry wt) } \\
\hline & $\mathrm{Fe}$ & $\mathrm{P}$ & As & $\mathrm{Fe}$ & $\mathrm{P}$ & As \\
\hline Control & $197.6 \pm 12.7 \mathrm{~A}$ & $2,138.4 \pm 102.7 \mathrm{~A}$ & $2.4 \pm 0.1 \mathrm{AB}$ & $5,591.1 \pm 1,211.3 \mathrm{AB}$ & $685.6 \pm 27.2 \mathrm{~A}$ & $73.0 \pm 6.3 \mathrm{~A}$ \\
\hline $\mathrm{KNO}_{3}$ & $161.4 \pm 2.6 \mathrm{~A}$ & $1,711.1 \pm 50.4 \mathrm{~B}$ & $1.6 \pm 0.1 \mathrm{~B}$ & $2,954.5 \pm 536.1 \mathrm{~B}$ & $658.3 \pm 21.7 \mathrm{~A}$ & $39.8 \pm 2.7 \mathrm{~B}$ \\
\hline $\mathrm{NH}_{4} \mathrm{Cl}$ & $208.3 \pm 31.2 \mathrm{~A}$ & $1,889.5 \pm 55.1 \mathrm{~B}$ & $2.6 \pm 0.2 \mathrm{~A}$ & $9,900.3 \pm 2,236.9 \mathrm{~A}$ & $605.2 \pm 54.2 \mathrm{~A}$ & $82.1 \pm 13.5 \mathrm{~A}$ \\
\hline
\end{tabular}

a Values are presented as the mean \pm standard error $(n=4)$. Different uppercase letters indicate a significant difference (one-way analysis of variance, $p<0.05$ ) between the means of each treatment (control or $\mathrm{N}$ fertilizer) in rice plants (root and shoot).

Fe(II) oxidizers was approximately one order of magnitude higher in the nonrhizosphere than in the rhizosphere irrespective of the treatment.

The MPN enumerations showed that nitrate amendment led to a slight increase in the number of nitrate-depending, Fe(II)oxidizing microorganisms in the nonrhizosphere (from $1.1 \times$ $10^{6}$ to $2.0 \times 10^{6}$ cells/g dry wt), whereas in the rhizosphere, the number decreased slightly. The paddy soil with the addition of ammonia showed lower numbers of nitrate-dependent, $\mathrm{Fe}(\mathrm{II})$-oxidizing microorganisms in both the rhizosphere $(2.1$ $\times 10^{4}$ cells/g dry wt $)$ and nonrhizosphere $\left(2.8 \times 10^{5}\right.$ cells/g dry wt) compared with the other two treatments.

\section{DISCUSSION}

\section{Inhibition of $\mathrm{Fe}(\mathrm{III})$ reduction by nitrate addition}

After flooding of the paddy fields, the soil largely becomes anoxic, and the Fe(III) minerals get reduced. Our initial experimental data showed that less dissolved Fe(II) was released over time from the sterilized soil compared with the nonsterilized soil, indicating an active biotic Fe transformation in the nonsterilized soil (data not shown). In the present study, we observed that after flooding, dissolved Fe(II) got released, and as a consequence, the $\mathrm{Fe}$ (II) concentration in the soil solution increased quickly during the first week after flooding. Dissolved Fe(II) concentrations in microcosms amended with nitrate, however, were much lower than those in the control and ammonia treatment. Although the results of MPN enumeration of nitrate-dependent $\mathrm{Fe}$ (II) oxidizers in the rhizosphere and nonrhizosphere showed that nitrate addition did not stimulate the proliferation of the bacteria substantially, the MPN results still suggest both a high abundance of nitrate-dependent Fe(II) oxidizers in the paddy soil and that microbial catalysis of the nitrate-dependent $\mathrm{Fe}$ (II) oxidation was likely to occur in the bulk soil. Evidence for nitrate-dependent $\mathrm{Fe}(\mathrm{II})$ oxidation in paddy soil also recently was given by Matocha and Coyne [38]. They demonstrated that both dissolved Fe(II) and oxalateextractable $\mathrm{Fe}$ (II) (the oxalate was used to extract $\mathrm{Fe}$ (II) mineral phases such as magnetite and siderite and poorly crystalline $\mathrm{Fe}(\mathrm{III})$ minerals and adsorbed $\mathrm{Fe}(\mathrm{II})$ ) were not constant during $\mathrm{NO}_{3}^{-}$reduction but, rather, dropped below the level in the corresponding control, indicating that $\mathrm{Fe}(\mathrm{II})$ was oxidized during $\mathrm{NO}_{3}^{-}$reduction and that nitrate inhibited $\mathrm{Fe}(\mathrm{II})$ production. It is difficult to separate the contributions of microbially catalyzed, anoxic Fe(II) oxidation by autotrophic or mixotrophic, $\mathrm{NO}_{3}^{-}$-dependent $\mathrm{Fe}(\mathrm{II})$ oxidation from chemical reoxidation of $\mathrm{Fe}(\mathrm{II})$ by $\mathrm{NO}_{2}^{-}$that is produced during concomitant $\mathrm{NO}_{3}^{-}$reduction on the basis of our data. In the treatment with ammonia, however, the first and rate-limiting step of the nitrification process is the oxidation of the $\mathrm{NH}_{4}^{+}$to $\mathrm{NO}_{2}^{-}$and then to $\mathrm{NO}_{3}^{-}$. The oxidation can occur only in the rhizosphere and surface layer, and the produced $\mathrm{NO}_{3}^{-}$was rapidly taken up by the plants or used for microbial denitrification. Therefore, no inhibition of $\mathrm{Fe}(\mathrm{III})$ reduction could occur in the nonrhizosphere in the treatment with ammonia, as observed in the present study (Fig. 2A). The difference in the profiles of dissolved $\mathrm{Fe}(\mathrm{II})$ in the soil solution with different $\mathrm{N}$ amendments suggest three possible zones for $\mathrm{Fe}(\mathrm{II})$ oxidation in this pot experiment: Rhizosphere, nonrhizosphere, and rice root surface. Our data suggest that more Fe(II) oxidation occurred on the root surface in the control and ammonia treatment than in the $\mathrm{NO}_{3}^{-}$amendment. After nitrate amendment, most $\mathrm{Fe}$ (II) oxidation occurred in the nonrhizosphere. Other studies have demonstrated that rice plants grown in flooded soil influence the Fe profiles because of the diffusive release of oxygen from the roots into rhizosphere soil [39]. Ferrous ion is subject to spontaneous chemical oxidation by dissolved $\mathrm{O}_{2}$ at circumneutral $\mathrm{pH}$ in the rhizosphere, which results in $\mathrm{Fe}$ plaque on the root surface. In our experiments, the reddish Fe plaque was observed on the root surface irrespective of different $\mathrm{N}$ amendments. The amount of Fe plaque deposited on the root surface in the nitrate treatment, however, was much less compared to that in the control and ammonia amendment, implying another zone of $\mathrm{Fe}$ (II) oxidation in addition to the rhizosphere and root surface. Liesack et al. [40] also observed a zone of Fe oxidation, as indicated by high Fe(III) concentrations below a soil depth of $3 \mathrm{~mm}$, where oxygen is depleted and Fe oxidation can occur only by oxygen-independent processes. In this zone, the electron acceptor used for anaerobic microbial $\mathrm{Fe}(\mathrm{II})$ oxidation could be nitrate. The present results further strengthen the suggestion that nitrate-dependent Fe(II) oxidiz-

Table 2. Most probable number (MPN) enumerations of nitrate-dependent, Fe (II)-oxidizing microorganisms in nonrhizosphere and rhizosphere paddy soil after $34 \mathrm{~d}^{\mathrm{a}}$

\begin{tabular}{|c|c|c|c|c|}
\hline \multirow[b]{2}{*}{ Treatment } & \multicolumn{2}{|c|}{ Nonrhizosphere (cells/g) } & \multicolumn{2}{|c|}{ Rhizosphere (cells/g) } \\
\hline & MPN & $95 \% \mathrm{CI}$ & MPN & $95 \% \mathrm{CI}$ \\
\hline Control & $1.1 \times 10^{6}$ & $3.0 \times 10^{5}$ to $4.3 \times 10^{6}$ & $2.0 \times 10^{5}$ & $5.9 \times 10^{4}$ to $7.1 \times 10^{5}$ \\
\hline $\mathrm{KNO}_{3}$ & $2.0 \times 10^{6}$ & $5.9 \times 10^{5}$ to $7.1 \times 10^{6}$ & $1.5 \times 10^{5}$ & $4.1 \times 10^{3}$ to $5.2 \times 10^{5}$ \\
\hline $\mathrm{NH}_{4} \mathrm{Cl}$ & $2.8 \times 10^{5}$ & $7.7 \times 10^{4}$ to $9.9 \times 10^{5}$ & $2.1 \times 10^{4}$ & $6.1 \times 10^{3}$ to $7.3 \times 10^{4}$ \\
\hline
\end{tabular}

${ }^{\mathrm{a}} \mathrm{CI}=$ confidence interval. 
ers are present in paddy soil, that $\mathrm{Fe}(\mathrm{II})$ oxidation coupled to nitrate reduction occurs in nonrhizosphere soil, and subsequently, that less mobile $\mathrm{Fe}$ (II) can diffuse toward the root surface and result in less $\mathrm{Fe}(\mathrm{III})$ minerals precipitating onto the root surface.

\section{Consequences of microbial Fe(II) oxidation for As and $P$}

In the present study, with $\mathrm{NO}_{3}^{-}$amendment the amounts of Fe plaque formed at the root surface as well as of As and $\mathrm{P}$ associated with the Fe plaque were much less than those in the control and ammonium-amended setups. This could be ascribed to the decrease in dissolved Fe(II) in the soil solution because of the microbially catalyzed $\mathrm{Fe}(\mathrm{II})$ oxidation in the bulk soil stimulated by the addition of $\mathrm{NO}_{3}^{-}$during the incubation and/or inhibition of $\mathrm{Fe}$ (III) reduction by nitrate. When $\mathrm{Fe}(\mathrm{II})$ is oxidized coupled to the reduction of $\mathrm{NO}_{3}^{-}$, arsenate is expected to efficiently associate with ferric $\mathrm{Fe}$ produced by this reaction, because $\mathrm{Fe}$ (hydr)oxides retain both $\mathrm{As}(\mathrm{V})$ and As(III) and, thus, often control As concentrations in soil solution $[41,42]$. We expected (and observed in our experiments) that $\mathrm{Fe}$ (II) oxidation to $\mathrm{Fe}$ (III) in the nonrhizosphere leads to the coprecipitation of As, thus decreasing the concentrations of $\mathrm{Fe}(\mathrm{II}), \mathrm{As}$, and possibly, $\mathrm{P}$ in soil solution and, subsequently, the mobility/bioavailability of As (and Fe(II)) in the soil. In addition, the oxidized Fe compounds deposited on the root, with chemical and physical properties similar to those of $\mathrm{Fe}$ oxides in soil, also have a high capacity for binding $\mathrm{P}$ and As [43]. The overall balance of Fe and As in soil solution and those associated with $\mathrm{Fe}$ plaque/Fe oxides control the plant uptake of $\mathrm{P}$ and As. The amount of As transported into the shoot was only a small proportion (1.28-1.72\%) of the As(tot) in $\mathrm{Fe}$ plaque and root, suggesting that $\mathrm{Fe}$ plaque at the roots and Fe minerals precipitated in the bulk soil represent a major As buffer in the soil-rice system [4,5]. In the ammonia treatment, higher concentrations of dissolved Fe(II) resulted in higher Fe plaque formation at the rice root, which is expected to sequester As and to limit As uptake by the plant. The high As uptake by plants that we observed probably resulted from the presence of a much higher As concentration in soil solution, diminishing the effect of Fe plaque. On the other hand, the lower As uptake by the rice plants grown with nitrate amendment probably resulted from a lower As concentration in soil solution (because of As removal already in the bulk soil). In this case, lower Fe plaque formation on the root, which also limits As uptake, probably was less important for the lower As uptake by the rice plant. These results suggested a way of regulating the $\mathrm{Fe}$ plaque formation, possibly by stimulating nitrate-dependent Fe(II) oxidation, which can finally influence the As speciation in the natural environment and its mobility and toxicity. This also was demonstrated in an urban lake system by Senn and Hemond [22], who found that the anaerobic Fe-N redox cycling influenced the oxidation and coprecipitation of $\mathrm{Fe}(\mathrm{III})$ and $\mathrm{As}(\mathrm{V})$ in lake sediment. Here, we show that the $\mathrm{Fe}-\mathrm{N}$ cycling in paddy soil influenced Fe plaque formation and, subsequently, As uptake by rice.

\section{Fe- $N$ redox cycling in paddy soil}

Oxidation of $\mathrm{Fe}(\mathrm{II})$ coupled to nitrate reduction provided the potential for a tight coupling between $\mathrm{N}$ and $\mathrm{Fe}$ redox cycles in paddy soil. The addition of $\mathrm{NO}_{3}^{-}$could inhibit $\mathrm{Fe}(\mathrm{III})$ reduction and/or stimulate $\mathrm{Fe}$ (II) oxidation in the bulk soil, thus reducing the transport of $\mathrm{Fe}$ (II) to the rhizosphere, leading to less Fe plaque formation at the rice plant roots. In contrast, the amendment of $\mathrm{NH}_{4}^{+}$increased $\mathrm{Fe}$ (II) concentration in the nonrhizosphere soil solution, and more Fe(II) diffused to the rhizosphere, leading to more Fe plaque formation on the root surface. This tight coupling between Fe and $\mathrm{N}$ may have practical implications. Nitrogen usually is supplied as urea to increase rice growth yield; however, recent studies also show that applying some $\mathrm{NO}_{3}^{-}-\mathrm{N}$ to paddy soil may be beneficial to rice growth [44]. In addition to the application of different sources of $\mathrm{N}$, abiotic and aerobic/anaerobic processes promote the $\mathrm{N}$ cycling in a rice field. No substantial $\mathrm{NO}_{3}^{-}$was detected in the rhizosphere or nonrhizosphere soil solutions in our pot experiments, indicating that $\mathrm{NO}_{3}^{-}$was consumed rapidly. Some studies have indicated high rates of coupled nitrification-denitrification in the rhizosphere, and even higher rates of nitrification should be expected at the surface of recently fertilized soil [45]. Nitrification occurred in the oxic parts of the paddy soil, such as the floodwater-soil interface and oxic rhizosphere, and nitrate produced in these processes would diffuse to anoxic soil. Reduction of $\mathrm{NO}_{3}^{-}$in flooding soil is dominated by ammonification and denitrification, which are inhibited by oxygen, and generally occurred in the anoxic nonrhizosphere. Recently, Clément et al. [46] measured an unexpected production of both nitrite and ferrous Fe under strictly anoxic conditions and, thus, hypothesized that a biological process uses ferric $\mathrm{Fe}$ as an electron accepter while oxidizing ammonia to nitrite for energy production. Therefore, a tight coupling of $\mathrm{N}$ and $\mathrm{Fe}$ cycles is expected in flooded paddy soil. Nitrate and Fe(II) may accumulate at the interface of oxic and anoxic zones (e.g., at the root surface) or after diffusion of the nitrate to anoxic zones in $\mathrm{O}_{2}$-free areas. While in the anoxic zones, nitratedependent $\mathrm{Fe}$ (II) oxidation can be catalyzed biotically, and the rhizosphere is a site of unusually active microbial Fe cycling [47]. In addition to the abiotic effect of nitrate on Fe redox cycling, rapid Fe-N cycling in paddy soil also results from the activity of microorganisms (e.g., Fe(III)-reducing bacteria coupled to nitrification and nitrate-dependent, Fe(II)-oxidizing bacteria) and rice root. Iron-nitrogen cycling in paddy soil has the potential to influence As and Fe dynamics in paddy soil and, subsequently, the uptake of As by rice. Further studies regarding the functional groups of bacteria that are dominant in this cycling are needed.

Acknowledgement-The present study was supported by the Natural Science Foundation of China (40671102 and 20477055) and the Global Explorations Funds initiated and funded by National Geographic and Bayer AG. A. Kappler is supported by an Emmy-Noether Fellowship from the German Research Foundation.

\section{REFERENCES}

1. Meharg AA, Rahman M. 2003. Arsenic contamination of Bangladesh paddy field soils: Implications for rice contribution to arsenic consumption. Environ Sci Technol 37:229-234.

2. Williams PN, Price AH, Raab A, Hossain SA, Feldmann J, Meharg AA. 2005. Variation in arsenic speciation and concentration in paddy rice related to dietary exposure. Environ Sci Technol 39:5531-5540.

3. Chen Z, Zhu YG, Liu WJ, Meharg AA. 2005. Direct evidence showing the effect of root surface iron plaque on arsenite and arsenate uptake into rice (Oryza sativa L.) roots. New Phytol 165: 91-97.

4. Liu WJ, Zhu YG, Hu Y, Williams PN, Gualt AG, Meharg AA, Charnock JM, Smith FA. 2006. Arsenic sequestration in iron plaque, its accumulation and speciation in mature rice plants (Oryza sativa L.). Environ Sci Technol 40:5730-5736.

5. Meharg AA. 2004. Arsenic in rice-Understanding a new disaster for southeast Asia. Trends Plant Sci 9:415-417. 
6. Ponnamperuma FN. 1972. The chemistry of submerged soils. Adv Agron 24:29-96.

7. Kirk GJD. 2004. The Biogeochemistry of Submerged Soil. Wiley, Chichester, UK.

8. Ratering S, Schnell S. 2001. Nitrate-dependent iron (II) oxidation in paddy soil. Environ Microbiol 3:100-109.

9. Hafenbradl D, Keller M, Dirmeier R, Rachel R, Roßnagel P, Burggraf S, Huber H, Stetter KO. 1996. Ferroglobus placidus gen. nov., sp. nov., a novel hyperthermophilic archaeum that oxidizes $\mathrm{Fe}^{2+}$ at neutral $\mathrm{pH}$ under anoxic conditions. Arch Microbiol 166: 308-314.

10. Straub KL, Benz M, Schink B, Widdel F. 1996. Anaerobic, nitratedependent microbial oxidation of ferrous iron. Appl Environ $\mathrm{Mi}$ crobiol 62:1458-1460.

11. Weber KA, Pollock J, Cole KA, O'Connor SM, Achenbach LA, Coates JD. 2006. Anaerobic nitrate-dependent iron(II) bio-oxidation by a novel lithoautotrophic betaproteobacterium, strain 2002. Appl Environ Microbiol 72:686-694.

12. Straub KL, Buchholz-Cleven BEE. 1998. Enumeration and detection of anaerobic ferrous-iron oxidizing nitrate-reducing bacteria from diverse European sediments. Appl Environ Microbiol 34:181-186.

13. Chaudhuri SK, Lack JG, Coates JD. 2001. Biogenic magnetite formation through anaerobic bio-oxidation of Fe(II). Appl Environ Microbiol 67:2844-2848.

14. Hauck S, Benz M, Brune A, Schink B. 2001. Ferrous iron oxidation by denitrifying bacteria in profundal sediments of a deep lake (Lake Constance). FEMS Microbiol Ecol 37:127-134.

15. Nielsen JL, Nielsen PH. 1998. Microbial Fe(II)-oxidation by nitrate in activated sludge. Water Sci Technol 37:403-406.

16. Nielsen JL, Nielsen PH. 1998. Microbial nitrate-dependent oxidation of ferrous iron in activated sludge. Environ Sci Technol 32:3556-3561.

17. Klüber HD, Conrad R. 1998. Effects of nitrate, nitrite, NO, and $\mathrm{N}_{2} \mathrm{O}$ on methanogenesis and other redox process in anoxic rice field soil. FEMS Microbiol Ecol 25:301-318.

18. Ratering S, Schnell S. 2000. Localization of iron-reducing activity in paddy soil by profile studies. Biogeochemistry 48:341-365.

19. Benz M, Brune A, Schink B. 1998. Anaerobic and aerobic oxidation of ferrous iron at neutral $\mathrm{pH}$ by cheoheterotrophic nitratereducing bacteria. Arch Microbiol 169:159-165.

20. Kappler A, Schink B, Newman DK. 2005. Fe(III)-mineral formation and cell encrustation by the nitrate-dependent Fe(II)-oxidizer strain BoFeN1. Geobiology 3:235-245.

21. Weber KA, Picardal FW, Roden EE. 2001. Microbially catalyzed nitrate-dependent oxidation of biogenic solid-phase Fe(II) compounds. Environ Sci Technol 35:1644-1650.

22. Senn DB, Hemond HF. 2002. Nitrate controls on iron and arsenic in an urban lake. Science 296:2373-2376.

23. Greipsson S. 1994. Effect of plaque on roots of rice on growth and metal concentration of seeds and plant tissues when cultivated in excess Cu. Commun Soil Sci Plant Anal 25:2761-2769.

24. Liu WJ, Zhu YG, Smith FA. 2005. Effects of iron and manganese plaques on arsenic uptake of by rice seedlings (Oryza sativa L.) grown in solution culture supplied with arsenate and arsenite. Plant Soil 277:127-138.

25. Ye ZH, Backer AJM, Wong MH, Willis AJ. 1997. Copper and nickel uptake, accumulation and tolerance in Typha latifolia with and without iron plaque on the root surface. New Phytol 136: 481-488.

26. Ye ZH, Backer AJM, Wong MH, Willis AJ. 1997. Zink, lead, and cadmium tolerance, uptake and accumulation in populations of Typha latifolia L. New Phytol 136:469-480.

27. Ye ZH, Backer AJM, Wong MH, Willis AJ. 1998. Zink, lead, and cadmium accumulation and tolerance in Typha as affected by iron plaque on the root surface. Aquat Bot 61:55-67.

28. Trivedt P, Axe L. 2000. Modeling Cd and Zn sorption to hydrous metal oxides. Environ Sci Technol 34:2215-2223.

29. Liu WJ, Zhu YG, Smith FA, Smith SE. 2004. Do phosphorus nutrition and iron plaque alter arsenate (As) uptake by rice seedlings in hydroponic culture? New Phytol 162:481-488.

30. Chabbi A, Hines ME, Rumpel C. 2001. The role organic carbon excretion by bulbous rush roots and its turnover and utilization by bacteria under iron plaques in extremely acid sediments. Environ Exp Bot 87:237-246.

31. Küsel K, Chabbi A, Trinkwalter T. 2003. Microbial processes associated with roots of bulbous rush coated with iron plaques. Microbial Ecol 46:302-311.

32. Ullah SM. 1998. Arsenic contamination of groundwater and irrigated soils of Bangladesh. Abstracts, International Conference on Arsenic Pollution of Groundwater in Bangladesh: Causes, Effects and Remedies. Dhaka Community Hospital, Dhaka, Bangladesh, February 8-12, p 133.

33. Zhang H, Young SD. 2006. Characterizing the availability of metals in contaminated soils. II. The soils solution. Soil Use Manag 21:459-467.

34. Yu C, Cai Q, Guo Z-Y, Yang Z, Khoo S B. 2003. Inductively coupled plasma-mass spectrometry study of the retention behavior of arsenic species on various solid-phase extraction cartridges and its application in arsenic speciation. Spectrochim Acta B At Spectrosc 58:1335-1349.

35. Taylor GJ, Crowder AA. 1983. Use of DCB technique for extraction of hydrous iron oxides from roots of wetland plants. Am J Bot 70:1254-1257.

36. Otte ML, Dekkers MJ, Rozema J, Broekman RA. 1991. Uptake of arsenic by Aster tripolium in relation to rhizosphere oxidation. Can J Bot 69:2670-2677.

37. Widdel F. 1983. Methods for enrichment and pure culture isolation of filamentous gliding sulfate-reducing bacteria. Arch Microbiol 134:282-285.

38. Matocha CJ, Coyne MS. 2007. Short-term response of soil iron to nitrate addition. Soil Sci Soc Am J 71:108-117.

39. Van der Nat FJWA, Middelburg JJ. 1998. Effects of two common macrophytes on methane dynamics in freshwater sediments. Biogeochemistry 43:79-104.

40. Liesack W, Schnell S, Revsbech NP. 2000. Microbiology of flooded rice paddies. FEMS Microbiol Rev 24:625-645.

41. Smedley PL, Kinniburgh DG. 2002. A review of the source, behavior, and distribution of arsenic in natural waters. Appl Geochem 17:517-568.

42. Dixit S, Hering JG. 2003. Comparison of arsenic(V) and arsenic(III) sorption onto iron oxide minerals: Implications for arsenic mobility. Environ Sci Technol 37:4128-4289.

43. Chistensen KK, Andersen FO, Jensen HS. 1997. Comparison of iron, manganese, and phosphorus retention in freshwater littoral sediment with growth of Littorella uniflora and benthic microalgae. Biogeochemistry 38:149-171.

44. Kirk GJD, Kronzucker HJ. 2005. The potential for nitrification and nitrate uptake in the rhizosphere of wetland plants: A modeling study. Ann Bot 96:639-646.

45. Reddy KR, Patrick WH. 1986. Fate of fertilizer nitrogen in the rice root zone. Soil Sci Soc Am J 50:649-651.

46. Clément JC, Shrestha J, Ehrenfeld JG, Jaffé PR. 2005. Ammonium oxidation coupled to dissimilatory reduction of iron under anaerobic conditions in wetland soils. Soil Biol Biochem 37: 2323-2328

47. Weiss JV, Emerson D, Megonigal JP. 2004. Geochemical control of microbial $\mathrm{Fe}(\mathrm{III})$ reduction potential in wetlands: Comparison of the rhizosphere to non-rhizosphere soil. FEMS Microbiol Ecol 48:89-100. 